\title{
Selective Oxidation of Methanol and Ethanol on Supported Ruthenium Oxide Clusters at Low Temperatures ${ }^{\dagger}$
}

\author{
Haichao Liu and Enrique Iglesia* \\ Department of Chemical Engineering, University of California at Berkeley, and Chemical Sciences Division, \\ E.O. Lawrence Berkeley National Laboratory, Berkeley, California 94720
}

Received: March 4, 2004

\begin{abstract}
$\mathrm{RuO}_{2}$ domains supported on $\mathrm{SnO}_{2}, \mathrm{ZrO}_{2}, \mathrm{TiO}_{2}, \mathrm{Al}_{2} \mathrm{O}_{3}$, and $\mathrm{SiO}_{2}$ catalyze the oxidative conversion of methanol to formaldehyde, methylformate, and dimethoxymethane with unprecedented rates and high combined selectivity $(>99 \%)$ and yield at low temperatures $(300-400 \mathrm{~K})$. Supports influence turnover rates and the ability of $\mathrm{RuO}_{2}$ domains to undergo redox cycles required for oxidation turnovers. Oxidative dehydrogenation turnover rates and rates of stoichiometric reduction of $\mathrm{RuO}_{2}$ in $\mathrm{H}_{2}$ increased in parallel when $\mathrm{RuO}_{2}$ domains were dispersed on more reducible supports. These support effects, the kinetic effects of $\mathrm{CH}_{3} \mathrm{OH}$ and $\mathrm{O}_{2}$ on reaction rates, and the observed kinetic isotope effects with $\mathrm{CH}_{3} \mathrm{OD}$ and $\mathrm{CD}_{3} \mathrm{OD}$ reactants are consistent with a sequence of elementary steps involving kinetically relevant $\mathrm{H}$-abstraction from adsorbed methoxide species using lattice oxygen atoms and with methoxide formation in quasi-equilibrated $\mathrm{CH}_{3} \mathrm{OH}$ dissociation on nearly stoichiometric $\mathrm{RuO}_{2}$ surfaces. Anaerobic transient experiments confirmed that $\mathrm{CH}_{3} \mathrm{OH}$ oxidation to $\mathrm{HCHO}$ requires lattice oxygen atoms and that selectivities are not influenced by the presence of $\mathrm{O}_{2}$. Residence time effects on selectivity indicate that secondary $\mathrm{HCHO}-\mathrm{CH}_{3} \mathrm{OH}$ acetalization reactions lead to hemiacetal or methoxymethanol intermediates that convert to dimethoxymethane in reactions with $\mathrm{CH}_{3} \mathrm{OH}$ on support acid sites or dehydrogenate to form methylformate on $\mathrm{RuO}_{2}$ and support redox sites. These conclusions are consistent with the tendency of $\mathrm{Al}_{2} \mathrm{O}_{3}$ and $\mathrm{SiO}_{2}$ supports to favor dimethoxymethane formation, while $\mathrm{SnO}_{2}, \mathrm{ZrO}_{2}$, and $\mathrm{TiO}_{2}$ preferentially form methylformate. These support effects on secondary reactions were confirmed by measured $\mathrm{CH}_{3} \mathrm{OH}$ oxidation rates and selectivities on physical mixtures of supported $\mathrm{RuO}_{2}$ catalysts and pure supports. Ethanol also reacts on supported $\mathrm{RuO}_{2}$ domains to form predominately acetaldehyde and diethoxyethane at 300-400 K. The bifunctional nature of these reaction pathways and the remarkable ability of $\mathrm{RuO}_{2}$-based catalysts to oxidize $\mathrm{CH}_{3} \mathrm{OH}$ to $\mathrm{HCHO}$ at unprecedented low temperatures introduce significant opportunities for new routes to complex oxygenates, including some containing $\mathrm{C}-\mathrm{C}$ bonds, using methanol or ethanol as intermediates derived from natural gas or biomass.
\end{abstract}

\section{Introduction}

Methanol oxidation reactions lead to formaldehyde ( $\mathrm{HCHO})$, dimethoxymethane $\left(\mathrm{CH}_{3} \mathrm{OCH}_{2} \mathrm{OCH}_{3}, \mathrm{DMM}\right)$, and methylformate $\left(\mathrm{HCOOCH}_{3}, \mathrm{MF}\right)$ products. Oxidative routes to $\mathrm{HCHO}$ are practiced on silver-based and iron-molybdate catalysts. ${ }^{1}$ Methylformate, a precursor to formamides, carboxylic acids, and their ethers, ${ }^{1,2}$ is produced via (nonoxidative) $\mathrm{CH}_{3} \mathrm{OH}$ dehydrogenation on $\mathrm{CuO}$ or carbonylation using liquid bases. ${ }^{2,3}$ The direct oxidative conversion of methanol to methylformate occurs only at modest reaction rates. ${ }^{2-5} \mathrm{DMM}$ is produced in a two-step process involving methanol oxidation to $\mathrm{HCHO}$ followed by acetalization of $\mathrm{HCHO}-\mathrm{CH}_{3} \mathrm{OH}$ mixtures with liquid or solid acids. Direct $\mathrm{CH}_{3} \mathrm{OH}$ oxidation with significant DMM yields has been recently reported on $\mathrm{ReO}_{x}$-based catalysts $^{6}$ and on polyoxometalate Keggin clusters. ${ }^{7}$

$\mathrm{CH}_{3} \mathrm{OH}$ oxidation to $\mathrm{MF}$ on $\mathrm{MoO}_{x}$ and $\mathrm{VO}_{x}$ catalysts involves rate-determining $\mathrm{C}-\mathrm{H}$ activation steps to form $\mathrm{HCHO}$ and subsequent $\mathrm{HCHO}$ reactions with intermediates derived from $\mathrm{CH}_{3} \mathrm{OH}$ or $\mathrm{HCHO}$. ${ }^{1,8,9}$ These intermediates also form $\mathrm{CO}_{x}$ at conditions required for $\mathrm{HCHO}$ synthesis. Acid-catalyzed acetalization is favored by thermodynamics at low temperatures, ${ }^{10}$

\footnotetext{
† Part of the special issue "Michel Boudart Festschrift".

* To whom correspondence should be addressed. E-mail: iglesia@ cchem.berkeley.edu; tel.: (510) 642-9673; Fax: (510) 642-4778.
}

current DMM synthesis routes form dimethyl ether and $\mathrm{CO}_{x}$ as undesired byproducts. Higher MF and DMM selectivities will require that $\mathrm{HCHO}$ intermediates be formed at lower temperatures than on existing catalysts.

$\mathrm{RuO}_{2}$ domains catalyze $\mathrm{CO}$ oxidation (at ambient temperatures), ${ }^{11}$ as well as the oxidation of $\mathrm{C}_{5}+$ alcohols to aldehydes and ketones (at $\sim 373 \mathrm{~K}$ ). ${ }^{12-14}$ Here, we report unprecedented methanol and ethanol oxidation rates and selectivities on $\mathrm{RuO}_{2}$ domains at very low temperatures $(300-400 \mathrm{~K})$ and a specific role of supports in directing $\mathrm{HCHO}-\mathrm{CH}_{3} \mathrm{OH}$ reactions toward MF or DMM products with high selectivity. We probe the redox character of the catalytic sequence, the nature of the kinetically relevant steps, and the relation between reduction dynamics and catalytic reactivity of $\mathrm{RuO}_{2}$ domains. These findings suggest selective routes to a broad range of complex oxygen-containing products via oxidative reactions of methanol and ethanol.

\section{Experimental Section}

Supported $\mathrm{RuO}_{2}$ catalysts were prepared by incipient wetness impregnation of $\mathrm{ZrO}_{2-x}(\mathrm{OH})_{2 x}, \mathrm{Sn}(\mathrm{OH})_{4}, \mathrm{TiO}_{2}$ (Degussa, P25), $\mathrm{Al}_{2} \mathrm{O}_{3}$ (Alcoa, HiQ31), $\mathrm{SiO}_{2}$ (Cab-O-Sil), and $\mathrm{MgO}$ with aqueous solutions of $\mathrm{Ru}(\mathrm{NO})\left(\mathrm{NO}_{3}\right)_{3} \cdot x \mathrm{H}_{2} \mathrm{O}$ (Aldrich, $56 \mathrm{wt} \%$ $\mathrm{Ru})$ at $298 \mathrm{~K}$ for $5 \mathrm{~h}$. Impregnated supports were dried in ambient air at $398 \mathrm{~K}$ overnight and then in flowing dry air 
(Airgas, zero grade, $0.7 \mathrm{~cm}^{3} / \mathrm{g}$-s) at $673 \mathrm{~K}$ for $2 \mathrm{~h} . \mathrm{ZrO}_{2-x}(\mathrm{OH})_{2 x}$, $\mathrm{Sn}(\mathrm{OH})_{4}$, and $\mathrm{MgO}$ were prepared as in previous reports. ${ }^{15}$ $\mathrm{ZrO}_{2-x}(\mathrm{OH})_{2 x}$ was prepared by hydrolysis of aqueous zirconyl chloride solutions ( $>98 \%$, Aldrich) at a $\mathrm{pH}$ of $\sim 10$ using $\mathrm{NH}_{4} \mathrm{OH}$ (14.8 N, Fisher Scientific), followed by filtration of precipitated powders, and treatment in ambient air at $393 \mathrm{~K}$ overnight. $\mathrm{SnO}_{2}$ was prepared by hydrolysis of tin (IV) chloride pentahydrate (98\%, Alfa Aesar) at a $\mathrm{pH}$ of $\sim 7$ using $\mathrm{NH}_{4} \mathrm{OH}$ (14.8 N, Fisher Scientific), followed by treatment of the resulting solids in dry air (Airgas, zero grade, $0.7 \mathrm{~cm}^{3} / \mathrm{g}$-s) at $773 \mathrm{~K}$ for $3 \mathrm{~h}$. $\mathrm{MgO}$ was prepared by contacting $\mathrm{MgO}$ ( $>98 \%$, Aldrich) with deionized water at 355-365 $\mathrm{K}$ for $4 \mathrm{~h}$, and then treating samples in flowing dry air (Airgas, zero grade, $0.7 \mathrm{~cm}^{3} / \mathrm{g}$-s) at $773 \mathrm{~K}$ for $8 \mathrm{~h} . \mathrm{Al}_{2} \mathrm{O}_{3}$ was treated in flowing dry air at $823 \mathrm{~K}$ for $5 \mathrm{~h}$ before use.

The nominal Ru surface density for each sample is reported as $\mathrm{Ru} / \mathrm{nm}^{2}$, based on the Ru content and BET surface area for each sample. Surface areas were measured using $\mathrm{N}_{2}$ at its normal boiling point (Autosorb-1; Quantachrome) and BET analysis methods. The dispersion of $\mathrm{Ru}$ crystallites was measured using $\mathrm{H}_{2}$ chemisorption at $313 \mathrm{~K}$ after reduction of $\mathrm{RuO}_{2}$ domains in $\mathrm{H}_{2}$ at $573 \mathrm{~K}$ for $1 \mathrm{~h}$ (Autosorb-1; Quantachrome). Repeated reduction-oxidation cycles did not influence measured dispersions, indicating that the resulting metal crystallites represent a reasonable relative measure of the dispersion of $\mathrm{RuO}_{2}$ clusters present during oxidation catalysis.

Reduction rates of supported $\mathrm{RuO}_{2}$ domains in $\mathrm{H}_{2}$ were measured using a Quantachrome analyzer (Quantachrome Corp.) modified with electronic flow controllers. Samples (2 mg Ru) were placed in a quartz cell ( $4 \mathrm{~mm}$ I.D.) containing a quartz well in contact with samples and heated linearly from 298 to $793 \mathrm{~K}$ at $0.167 \mathrm{~K} \mathrm{~s}^{-1}$ in flowing $20 \% \mathrm{H}_{2} / \operatorname{Ar}\left(1.33 \mathrm{~cm}^{3} \mathrm{~s}^{-1}\right)$ (Matheson UHP). The $\mathrm{H}_{2}$ content in the effluent was measured by thermal conductivity after $\mathrm{H}_{2} \mathrm{O}$ formed during reduction was removed from the effluent using a $13 \mathrm{X}$ sieve trap at ambient temperature. The thermal conductivity detector was calibrated by reducing $\mathrm{CuO}$ powder in $\mathrm{H}_{2}(99.995 \%$, Aldrich). Reduction rates were measured from $\mathrm{H}_{2}$ consumption rates using previously reported protocols. ${ }^{15,16}$

Methanol reactions were carried out in a packed-bed quartz microreactor. Catalyst powders $(0.1-0.3 \mathrm{~g})$ were diluted with quartz powder $(\sim 0.5 \mathrm{~g})$ to prevent temperature gradients and treated in $20 \% \mathrm{O}_{2} / \mathrm{He}\left(\mathrm{O}_{2}\right.$, Praxair, 99.999\%; He, Airgas, $99.999 \% ; 0.67 \mathrm{~cm}^{3} / \mathrm{s}$ ) flow at $573 \mathrm{~K}$ for $1 \mathrm{~h}$ before catalytic measurements. Reactants were $4 \mathrm{kPa} \mathrm{CH} 3 \mathrm{OH}$ (Merck, 99.99\%), $9 \mathrm{kPa} \mathrm{O}, 1 \mathrm{kPa} \mathrm{N}$ (Praxair, Certified $\mathrm{O}_{2} / \mathrm{N}_{2}$ mixture) and 86 $\mathrm{kPa}$ balance $\mathrm{He}$ (Airgas, 99.999\%). The kinetic effects of $\mathrm{CH}_{3} \mathrm{OH}(4-40 \mathrm{kPa})$ and $\mathrm{O}_{2}(4.5-28 \mathrm{kPa})$ pressures on $\mathrm{CH}_{3} \mathrm{OH}$ reaction rates and selectivities were also examined. Similar procedures were used for $\mathrm{CH}_{3} \mathrm{OH}$ and $\mathrm{C}_{2} \mathrm{H}_{5} \mathrm{OH}$ (99.5\% Aldrich) reactants. $\mathrm{CH}_{3} \mathrm{OD}$ (CDN Isotopes, 99.6 at. \% D) and $\mathrm{CD}_{3} \mathrm{OD}$ (Cambridge Isotopes, 99.8 at. \% D) were used as reactants to measure kinetic isotope effects.

Reactants and products were analyzed by on-line gas chromatography (Hewlett-Packard 6890GC) using a methyl-silicone capillary column (HP-1; $50 \mathrm{~m} \times 0.25 \mathrm{~mm}, 0.25 \mu \mathrm{m}$ film thickness) and a Porapak Q packed column (80-100 mesh, 1.82 $\mathrm{m} \times 3.18 \mathrm{~mm}$ ) connected to flame ionization and thermal conductivity detectors, respectively. Selectivities are reported on a carbon basis as the percentage of the converted $\mathrm{CH}_{3} \mathrm{OH}$ appearing as a given product. Rates are reported as the molar $\mathrm{CH}_{3} \mathrm{OH}$ conversion rates per total $\mathrm{Ru}$ or surface $\mathrm{Ru}$ atom. Blank experiments using empty reactors did not lead to detectable $\mathrm{CH}_{3} \mathrm{OH}$ conversions at any of the conditions of our study.
Anaerobic $\mathrm{CH}_{3} \mathrm{OH}$ reactions were carried out in transient mode using a packed-bed quartz microreactor to determine the role of lattice oxygen atoms and the involvement of redox pathways in $\mathrm{CH}_{3} \mathrm{OH}$ oxidation on $\mathrm{RuO}_{2}$ domains. Samples $(0.1-0.3 \mathrm{~g})$ were diluted with quartz powder $(\sim 0.5 \mathrm{~g})$ and treated in $20 \% \mathrm{O}_{2} / \mathrm{He}\left(\mathrm{O}_{2}\right.$, Praxair, 99.999\%; He, Airgas, $99.999 \% ; 0.67 \mathrm{~cm}^{3} / \mathrm{s}$ ) flow at $573 \mathrm{~K}$ for $1 \mathrm{~h}$. Steady-state $\mathrm{CH}_{3} \mathrm{OH}$ oxidation reactions were carried out in $4 \mathrm{kPa} \mathrm{CH} \mathrm{CH}_{3} \mathrm{OH}$ $\left(1 \mathrm{~cm}^{3}\right.$ (STP) s ${ }^{-1}$ Merck, 99.99\%), $9 \mathrm{kPa} \mathrm{O}, 1 \mathrm{kPa} \mathrm{N}$ (Praxair, $_{2}$ Certified $\mathrm{O}_{2} / \mathrm{N}_{2}$ mixture) with $\mathrm{He}$ as balance (Airgas, $99.999 \%$ ) before this reactant mixture was flushed with pure $\mathrm{He}\left(1 \mathrm{~cm}^{3}\right.$ $\mathrm{s}^{-1}$ ) for $300 \mathrm{~s}$. Then, a mixture $\mathrm{CH}_{3} \mathrm{OH}(4 \mathrm{kPa})$ diluted with $\mathrm{He}$ was passed over the samples until $\mathrm{CH}_{3} \mathrm{OH}$ conversion was no longer detected. Finally, $\mathrm{O}_{2}$ was introduced into this $\mathrm{CH}_{3} \mathrm{OH} /$ He mixture to confirm the recovery of initial catalytic oxidation turnover rates after these anaerobic transients. Reactants and products were analyzed every $8 \mathrm{~s}$ using on-line mass spectroscopy (Hewlett-Packard 5972, mass selective detector) during these experiments.

\section{Results and Discussion}

Table 1 shows $\mathrm{CH}_{3} \mathrm{OH}$ oxidation rates (normalized by either total or surface-exposed $\mathrm{Ru}$ atoms) and selectivities at $393 \mathrm{~K}$ on $\mathrm{RuO}_{2}$ domains supported on $\mathrm{SiO}_{2}, \mathrm{Al}_{2} \mathrm{O}_{3}, \mathrm{ZrO}_{2}, \mathrm{TiO}_{2}, \mathrm{SnO}_{2}$, and $\mathrm{MgO}$ with similar $\mathrm{Ru}$ fractional dispersion $(0.174-0.215)$ and crystallite diameters $(6.0-7.6 \mathrm{~nm}$; from $\mathrm{Ru}$ dispersion assuming hemispherical crystallites). Raman spectra for these samples showed that $\mathrm{RuO}_{2}$ species were well-dispersed on support surfaces, as evidenced by weak Raman features at 533, 637 , and $712 \mathrm{~cm}^{-1}$ (data not shown), corresponding to $\mathrm{E}_{\mathrm{g}}, \mathrm{A}_{1 \mathrm{~g}}$, and $\mathrm{B}_{2 \mathrm{~g}}$ modes, respectively. ${ }^{17}$ The weak nature of these features is consistent with small $\mathrm{RuO}_{2}$ structures, as also inferred from measured chemisorption uptakes on reduced forms of these samples.

$\mathrm{HCHO}, \mathrm{MF}$, DMM, and $\mathrm{CO}_{2}$ were detected as products; neither $\mathrm{CO}$ nor dimethyl ether products were detected. Rates and selectivities are compared at similar $\mathrm{CH}_{3} \mathrm{OH}$ conversions ( $\sim 20 \%$ ) in Table 1 , because relative contributions of primary and secondary reactions depend on residence time and $\mathrm{CH}_{3} \mathrm{OH}$ conversion, as discussed later. $\mathrm{CH}_{3} \mathrm{OH}$ turnover rates were higher on $\mathrm{RuO}_{2}$ supported on $\mathrm{SnO}_{2}, \mathrm{ZrO}_{2}$, and $\mathrm{TiO}_{2}$ than on $\mathrm{Al}_{2} \mathrm{O}_{3}$ or $\mathrm{SiO}_{2}$, while $\mathrm{RuO}_{2}$ supported on $\mathrm{MgO}$ led to nearly undetectable $\mathrm{CH}_{3} \mathrm{OH}$ conversions. Turnover rates changed by less than $5 \%$ during catalytic experiments $(\sim 15 \mathrm{~h})$. Bulk $\mathrm{RuO}_{2}$ (Aldrich, 99.9\%) with relatively low surface area gave very low $\mathrm{CH}_{3} \mathrm{OH}$ conversion rates (Table 1). Pure supports did not give detectable $\mathrm{CH}_{3} \mathrm{OH}$ conversion rates in the absence of $\mathrm{RuO}_{2}$, even at $473 \mathrm{~K}$, a temperature much higher than required for significant conversions on $\mathrm{RuO}_{2}$-containing samples.

As discussed below, $\mathrm{CH}_{3} \mathrm{OH}$ oxidation requires ratedetermining $\mathrm{C}-\mathrm{H}$ activation in $\mathrm{CH}_{3} \mathrm{OH}$-derived methoxide intermediates to form $\mathrm{HCHO}$ through redox cycles using lattice oxygen atoms within $\mathrm{RuO}_{x}$ domains. HCHO then reacts in subsequent reactions with $\mathrm{CH}_{3} \mathrm{OH}$ to form hemiacetal or methoxymethanol intermediates $\left(\mathrm{CH}_{3} \mathrm{OCH}_{2} \mathrm{OH}\right),{ }^{5}$ which can undergo condensation reactions with $\mathrm{CH}_{3} \mathrm{OH}$ to form DMM or sequential hydrogen abstraction to form MF (Scheme 1). Reactions listed along the horizontal direction in Scheme 1 require acid sites, while those depicted along the vertical direction involve some reactive form of lattice oxygen $\left(\mathrm{O}^{*}\right)$ on either $\mathrm{RuO}_{2}$ domains or active supports.

The irreversible nature of the oxidative conversion of $\mathrm{CH}_{3} \mathrm{OH}$ to $\mathrm{HCHO}$ requires one oxidative $\mathrm{CH}_{3} \mathrm{OH}$ dehydrogenation $(\mathrm{ODH})$ event for each $\mathrm{HCHO}, \mathrm{DMM}$, and MF molecule formed. 
TABLE 1: Methanol Oxidation Rates and Selectivities on Supported $\mathrm{RuO}_{2}$ Catalysts at Similar Methanol Conversion $(\sim 20 \%){ }^{a}$ and on Previously Reported Catalysts

\begin{tabular}{|c|c|c|c|c|c|c|c|c|c|c|}
\hline \multirow{2}{*}{$\begin{array}{c}\text { catalyst } \\
\text { (Ru wt \%) }\end{array}$} & \multirow{2}{*}{$\begin{array}{c}\text { Ru surface } \\
\text { density } \\
\left(\mathrm{Ru} / \mathrm{nm}^{2}\right)\end{array}$} & \multirow{2}{*}{$\begin{array}{c}\text { temperature/ } \\
\mathrm{CH}_{3} \mathrm{OH} \\
\text { pressure } \\
(\mathrm{K} / \mathrm{kPa})\end{array}$} & \multirow{2}{*}{$\begin{array}{c}\mathrm{CH}_{3} \mathrm{OH} \\
\text { conversion rate } \\
\text { (mol/g-atom } \\
\left.\mathrm{M}_{\text {total }}-\mathrm{h}\right) \\
\end{array}$} & \multirow{2}{*}{$\begin{array}{c}\text { turnover rate } \\
\text { (mol/g-atom } \\
\left.\mathrm{Ru}_{\text {surf }}-\mathrm{h}\right)\end{array}$} & \multirow{2}{*}{$\begin{array}{c}\text { calculated ODH } \\
\text { turnover rate } \\
(\mathrm{mol} / \mathrm{g} \text {-atom } \\
\left.\mathrm{Ru}_{\text {surf }}-\mathrm{h}\right)\end{array}$} & \multirow{2}{*}{$\begin{array}{c}\text { initial } \\
\text { reduction rate } \\
(\mathrm{mol} \mathrm{H} / \\
\text { g-atom } \mathrm{Ru}-\mathrm{h})\end{array}$} & \multicolumn{4}{|c|}{ selectivity (\%) } \\
\hline & & & & & & & $\overline{\mathrm{HCHO}}$ & $\mathrm{MF}$ & DMM & $\overline{\mathrm{CO}_{x}}$ \\
\hline $\begin{array}{c}\mathrm{RuO}_{2} / \mathrm{SiO}_{2} \\
(4.3 \%)\end{array}$ & 1.1 & $393 / 4$ & 8.3 & 41.5 & 19.4 & 5.3 & 12.4 & 31.0 & 56.1 & 0.6 \\
\hline $\begin{array}{c}\mathrm{RuO}_{2} / \mathrm{Al}_{2} \mathrm{O}_{3} \\
(4.4 \%)\end{array}$ & 1.3 & $393 / 4$ & 14.9 & 71.0 & 32.5 & 7.5 & 11.6 & 30.1 & 57.4 & 1.0 \\
\hline $\begin{array}{c}\mathrm{RuO}_{2} / \mathrm{ZrO}_{2} \\
(4.1 \%)\end{array}$ & 2.1 & $393 / 4$ & 17.6 & 88.9 & 53.2 & 11.6 & 6.6 & 70.7 & 5.6 & 16.8 \\
\hline $\begin{array}{c}\mathrm{RuO}_{2} / \mathrm{TiO}_{2} \\
(2.2 \%)\end{array}$ & 3.1 & $393 / 4$ & 14.5 & 84.7 & 52.1 & 10.8 & 25.2 & 69.9 & 4.1 & 0.9 \\
\hline $\begin{array}{c}\mathrm{RuO}_{2} / \mathrm{SnO}_{2} \\
(4.1 \%)\end{array}$ & 2.5 & $393 / 4$ & 30.6 & 142.3 & 79.1 & 22.3 & 20.0 & 60.7 & 15.5 & 3.8 \\
\hline $\begin{array}{c}\mathrm{RuO}_{2} / \mathrm{SnO}_{2} \\
(4.1 \%)\end{array}$ & 2.5 & $333 / 4$ & 2.0 & 9.3 & 5.0 & & 10.2 & 83.1 & 6.7 & 0 \\
\hline $\begin{array}{c}\mathrm{RuO}_{2} / \mathrm{SnO}_{2}{ }^{c} \\
(4.1 \%)\end{array}$ & 2.5 & $333 / 80$ & 4.3 & 19.9 & 8.7 & & 1.6 & 57.3 & 40.8 & 0 \\
\hline $\begin{array}{c}\mathrm{RuO}_{x} / \mathrm{Al}_{2} \mathrm{O}_{3}{ }^{c} \\
(4.4 \%)\end{array}$ & 1.3 & $333 / 80$ & 2.0 & 9.5 & 4.1 & & 9.4 & 23.4 & 66.8 & 0.4 \\
\hline $\begin{array}{c}\mathrm{RuO}_{2} / \mathrm{MgO} \\
(4.3 \%)\end{array}$ & 2.3 & $393 / 4$ & 0.3 & 1.7 & 1.4 & 0.4 & & & & \\
\hline bulk $\mathrm{RuO}_{2}$ & & $393 / 4$ & 2.3 & $26.7^{h}$ & $16.6^{h}$ & & 34.9 & 53.5 & 2.2 & 9.4 \\
\hline $\mathrm{V}_{2} \mathrm{O}_{5}-\mathrm{TiO}_{2}^{(2) d}$ & & $443 / 9$ & 3.4 & & & & 7 & 80 & 3 & 5 \\
\hline $\mathrm{Mo}-\mathrm{Sn}-\mathrm{O}^{(3) e}$ & & $433 / 6$ & 1.0 & & & & 5 & 90 & 0 & 2 \\
\hline $\mathrm{Mo}-\mathrm{Sn}-\mathrm{O}^{(4) f}$ & & $453 / 18$ & 1.8 & & & & 27.2 & 47.0 & 0 & 1.5 \\
\hline $\mathrm{MoO}_{3} / \mathrm{SiO}_{2}{ }^{(5) g}$ & & $533 / 7$ & 1.1 & & & & & 95.9 & - & 3.0 \\
\hline
\end{tabular}

${ }^{a}$ Ru dispersion: $0.174-0.215,9 \mathrm{kPa} \mathrm{O}, 1 \mathrm{kPa} \mathrm{N}_{2} .{ }^{b}$ Rate for primary $\mathrm{CH}_{3} \mathrm{OH}$ oxidative dehydrogenation to $\mathrm{HCHO} .{ }^{c} 80 \mathrm{kPa} \mathrm{CH}_{3} \mathrm{OH}, 18 \mathrm{kPa}$ $\mathrm{O}_{2}, 2 \mathrm{kPa} \mathrm{N}{ }{ }^{d} \sim 9 \mathrm{kPa} \mathrm{CH} \mathrm{H}_{3} \mathrm{OH}, \sim 10 \mathrm{kPa} \mathrm{O}_{2}$, balance $\mathrm{N}_{2}, \mathrm{~V} / \mathrm{Ti}$ (atomic ratio) $=0.0375 .{ }^{e} \sim 6 \mathrm{kPa} \mathrm{CH}_{3} \mathrm{OH}, \sim 4 \mathrm{kPa} \mathrm{O}_{2}$, balance $\mathrm{N}_{2}, \mathrm{Mo} / \mathrm{Sn}($ atomic ratio) $=3 / 7 .{ }^{f} 18 \mathrm{kPa} \mathrm{CH} 3 \mathrm{OH}, 7 \mathrm{kPa} \mathrm{O}$, balance $\mathrm{He}, \mathrm{Mo} / \mathrm{Sn}$ (atomic ratio) $=3 / 7 .{ }^{g} 7 \mathrm{kPa} \mathrm{CH} \mathrm{CH}_{3} \mathrm{OH}, 19 \mathrm{kPa} \mathrm{O}$, balance $\mathrm{He}$, 0.18 wt $\%$ Mo. ${ }^{h}$ Estimated by assuming the number of surface $\mathrm{Ru}$ atoms to be $10^{19} / \mathrm{m}^{2}$ for the bulk $\mathrm{RuO}_{2}$.

SCHEME 1: Proposed Primary and Secondary $\mathrm{CH}_{3} \mathrm{OH}$ Reaction Pathways

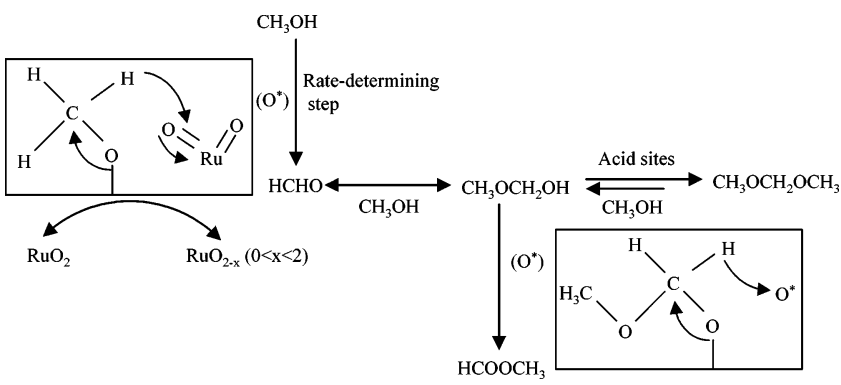

Thus, $\mathrm{ODH}$ rates are reported as the combined molar formation rates of these products; $\mathrm{ODH}$ rates rigorously reflect the intrinsic oxidation reactivity of active domains, without contributions from methanol molecules consumed because of various secondary reactions. ODH turnover rates (per exposed $\mathrm{Ru}$ ) are $\sim 1.5$ times greater when $\mathrm{RuO}_{2}$ was supported on $\mathrm{SnO}_{2}$ than on $\mathrm{ZrO}_{2}$ and $\mathrm{TiO}_{2}$ and 2.5-4 times greater than when supported on $\mathrm{Al}_{2} \mathrm{O}_{3}$ and $\mathrm{SiO}_{2}$ (Table 1). ODH rates are much lower and near our detection limits $(\sim 0.1 \mathrm{~mol} / \mathrm{g}$-atom- $\mathrm{Ru}-\mathrm{h})$ on $\mathrm{RuO}_{2} / \mathrm{MgO}$.

$\mathrm{SnO}_{2}$ supports led to $\mathrm{RuO}_{x}$ domains with the highest reactivity, to significant reaction rates even near ambient temperatures $(333 \mathrm{~K})$, and to combined selectivities to $\mathrm{MF}$, $\mathrm{HCHO}$, and DMM above $99 \%$ (and $83 \%$ MF selectivity) at $10 \%$ $\mathrm{CH}_{3} \mathrm{OH}$ conversion (Table 1). Higher $\mathrm{CH}_{3} \mathrm{OH}$ pressures (80 vs $4 \mathrm{kPa}$ ) increased reaction rates (by a factor of 2) and DMM selectivities (6.7 to 40.8\%) at the expense of lower MF selectivities (83.1 to 57.3\%). These $\mathrm{CH}_{3} \mathrm{OH}$ pressure effects are similar to those observed on $\mathrm{RuO}_{2} / \mathrm{Al}_{2} \mathrm{O}_{3}$ (Table 1); they reflect secondary DMM synthesis pathways influenced by thermodynamic constraints that become less severe as $\mathrm{CH}_{3} \mathrm{OH}$ pressure increases.



Figure 1. Temperature-programmed reduction profiles for $\mathrm{RuO}_{2}$ domains supported on $\mathrm{SnO}_{2}, \mathrm{ZrO}_{2}, \mathrm{TiO}_{2}, \mathrm{SiO}_{2}, \mathrm{Al}_{2} \mathrm{O}_{3}$, and $\mathrm{MgO}$ with similar $\mathrm{Ru}$ dispersion of $0.174-0.215$ (Ru surface densities: 1.1-3.1 $\mathrm{Ru} / \mathrm{nm}^{2}$ ).

The observed effects of support on ODH turnover rates (Table 1) reflect changes in the reactivity of $\mathrm{RuO}_{x}$ surfaces caused by concurrent effects of supports on $\mathrm{RuO}_{x}$ reducibility and thus on its ability to undergo reduction in kinetically relevant steps required for oxidation turnovers. Figure 1 shows incipient reduction rates for $\mathrm{RuO}_{2}$ domains using $\mathrm{H}_{2}$ as a stoichiometric reductant as the sample temperature increased from 298 to 793 $\mathrm{K}$. Incipient reduction rates obtained by a kinetic analysis of the low-temperature part of the first reduction peak in Figure 1 are shown for each sample in Table 1. Reduction peak temperatures increased by $\sim 30 \mathrm{~K}(416$ to $447 \mathrm{~K})$ as the support changed from $\mathrm{SnO}_{2}$ to $\mathrm{ZrO}_{2}, \mathrm{TiO}_{2}, \mathrm{Al}_{2} \mathrm{O}_{3}, \mathrm{SiO}_{2}$, and $\mathrm{MgO}$. $\mathrm{RuO}_{2} / \mathrm{SnO}_{2}$ shows two additional reduction peaks at $486 \mathrm{~K}$ and 
at $>620 \mathrm{~K}$ (not shown), which reflect $\mathrm{SnO}_{2}$ reduction at temperatures above those of catalytic relevance. $\mathrm{RuO}_{2}$ domains on $\mathrm{MgO}$ gave two reduction features at higher temperatures, suggestive of refractory $\mathrm{RuO}_{2}$ domains strongly interacting with $\mathrm{MgO} . \mathrm{H}_{2}$ consumption stoichiometries were $1.9-2.2 \mathrm{H}_{2} / \mathrm{Ru}$ for all samples, indicating that all $\mathrm{Ru}^{4+}$ cations in $\mathrm{RuO}_{2}$ (as detected by Raman spectroscopy) reduce completely to $\mathrm{Ru}^{0}$ during these $\mathrm{H}_{2}$ treatments.

Initial reduction rates were extracted by kinetic analysis of the incipient reduction region of the reduction profiles ${ }^{15,16}$ in Figure 1. These incipient reduction processes are most relevant to those occurring in nearly stoichiometric $\mathrm{RuO}_{2}$ during the redox cycles required for methanol oxidation turnovers, evidence for which is presented below from the observed kinetic effects of $\mathrm{CH}_{3} \mathrm{OH}$ and $\mathrm{O}_{2}$ on catalytic oxidation rates. $\mathrm{RuO}_{2}$ domains supported on reducible oxides $\left(\mathrm{SnO}_{2}, \mathrm{ZrO}_{2}\right.$, and $\left.\mathrm{TiO}_{2}\right)$ undergo more facile reduction than those supported on more insulating and refractory oxides $\left(\mathrm{Al}_{2} \mathrm{O}_{3}, \mathrm{SiO}_{2}\right.$, and $\left.\mathrm{MgO}\right)$ (Table 1). If hydrogen abstraction from methoxide intermediates by lattice $\mathrm{O}$-atoms is the kinetically relevant step during $\mathrm{HCHO}$ synthesis on $\mathrm{RuO}_{x}$, the rates of catalytic $\mathrm{CH}_{3} \mathrm{OH}$ oxidation and of incipient stoichiometric reduction in $\mathrm{H}_{2}$ should increase in parallel, as indeed was found (Figure 2). These reduction rates and the corresponding $\mathrm{CH}_{3} \mathrm{OH}$ oxidation rates (Table 1) are much higher than for previously reported catalysts based on $\mathrm{MoO}_{x}$ and $\mathrm{VO}_{x}$ domains. $^{2-5,15,16,18}$

Supports also influence $\mathrm{CH}_{3} \mathrm{OH}$ reaction selectivities on $\mathrm{RuO}_{x}$-based catalysts. Support effects on selectivities are reported at $\sim 20 \% \mathrm{CH}_{3} \mathrm{OH}$ conversion, but the trends observed are similar at other conversion levels. Acid functions on $\mathrm{Al}_{2} \mathrm{O}_{3}$ and $\mathrm{SiO}_{2}$ surfaces favor DMM synthesis (57.4 and $56.1 \%$ selectivity), but MF also forms (30.1 and 31.0\%). Supports, such as $\mathrm{SnO}_{2}, \mathrm{ZrO}_{2}$, and $\mathrm{TiO}_{2}$, with amphoteric surfaces or known hydrogenation-dehydrogenation functions, preferentially formed MF (60.7-70.7\%; Table 1). These effects of supports on selectivity indicate that secondary reactions of primary $\mathrm{HCHO}$ products can occur on support surfaces or that such surfaces can intercept reaction intermediates (i.e., $\mathrm{CH}_{3} \mathrm{OCH}_{2} \mathrm{OH}$ ) required for DMM or MF syntheses.

The role of supports in catalyzing $\mathrm{HCHO}-\mathrm{CH}_{3} \mathrm{OH}$ reactions or in some manner directing reaction intermediates toward a given product was confirmed by physically mixing supported $\mathrm{RuO}_{2}$ catalysts with additional amounts of various pure supports. $\mathrm{Al}_{2} \mathrm{O}_{3}$ addition to $\mathrm{RuO}_{2} / \mathrm{TiO}_{2}$ (3:1 support/catalyst mass; 393 $\mathrm{K}$ ) increased DMM selectivities from 8.9 to $41.9 \%$, while MF selectivity decreased from 65.2 to $45.2 \%$ (Table 2). Thus, $\mathrm{Al}_{2} \mathrm{O}_{3}$ supports, even in pure form, directed $\mathrm{HCHO}-\mathrm{CH}_{3} \mathrm{OH}$ reactions toward DMM, decreasing the availability of HCHO (or its intermediate reaction products) for MF synthesis on the $\mathrm{RuO}_{2}$ / $\mathrm{TiO}_{2}$ component of this composite catalyst. Conversely, DMM selectivities on $\mathrm{RuO}_{2} / \mathrm{Al}_{2} \mathrm{O}_{3}$ decreased from 57.4 to $32.6 \%$ when pure $\mathrm{TiO}_{2}$ (3:1 mass ratio) was added, while the MF selectivity markedly increased from 30.1 to $60.4 \%$; thus, $\mathrm{TiO}_{2}$ surfaces either converted $\mathrm{HCHO}-\mathrm{CH}_{3} \mathrm{OH}$ mixtures to $\mathrm{MF}$ or scavenged reactive gas-phase intermediates (e.g., $\mathrm{CH}_{3} \mathrm{OCH}_{2} \mathrm{OH}$; Scheme 1) that would have otherwise formed $\mathrm{DMM}$ on $\mathrm{Al}_{2} \mathrm{O}_{3}$ acid sites and directed them instead toward MF synthesis on $\mathrm{RuO}_{x}$ domains. Oxidative dehydrogenation rates were not influenced by mixing pure supports, consistent with the required involvement of $\mathrm{RuO}_{x}$ domains in the initial HCHO synthesis step. $\mathrm{CH}_{3} \mathrm{OH}$ consumption rates changed only to the extent required to satisfy the different $\mathrm{CH}_{3} \mathrm{OH}$ stoichiometric requirements for DMM and MF synthesis in secondary $\mathrm{CH}_{3} \mathrm{OH}-\mathrm{HCHO}$ reactions (Scheme 1).

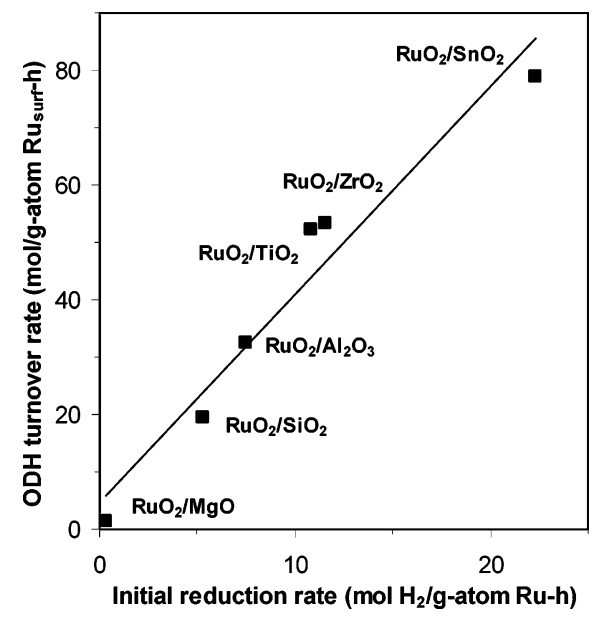

Figure 2. Dependence of rates of oxidative dehydrogenation (per g-atom surface $\mathrm{Ru}$ ) of $\mathrm{CH}_{3} \mathrm{OH}$ to $\mathrm{HCHO}$ at $393 \mathrm{~K}$ on initial reduction rates in $\mathrm{H}_{2}$ (per g-atom $\mathrm{Ru}$ ) at $403 \mathrm{~K}$ for $\mathrm{RuO}_{2}$ domains supported on $\mathrm{SnO}_{2}, \mathrm{ZrO}_{2}, \mathrm{TiO}_{2}, \mathrm{SiO}_{2}, \mathrm{Al}_{2} \mathrm{O}_{3}$, and $\mathrm{MgO}$ with similar $\mathrm{Ru}$ dispersion of $0.174-0.215$ (Ru surface densities: $1.1-3.1 \mathrm{Ru} / \mathrm{nm}^{2}$ ).

A plausible sequence of elementary steps for methanol oxidation on $\mathrm{RuO}_{x}$ domains is shown as steps $1-4$ below; it is consistent with the results presented above and with $\mathrm{HCHO}$ synthesis pathways previously proposed. $1,5,7,8$

$$
\begin{gathered}
\mathrm{CH}_{3} \mathrm{OH}+-\mathrm{O} *-\mathrm{Ru}-\mathrm{O} *-\mathrm{Ru}-\mathrm{O} *-\leftrightarrow \\
\left\{-\mathrm{O} *-\mathrm{Ru}_{-} \mathrm{OCH}_{3} \mathrm{HO}^{*}-\mathrm{Ru}-\mathrm{O} *-\right\} \\
\left\{-\mathrm{O} *-\mathrm{Ru}-\mathrm{OCH}_{3} \mathrm{HO}^{*}-\mathrm{Ru}-\mathrm{O} *-\right\} \rightarrow \\
\{\mathrm{HO} *-\mathrm{Ru}-\mathrm{O} *-\mathrm{Ru}-* \mathrm{OH}\}+\mathrm{HCHO}
\end{gathered}
$$

$$
\left\{\mathrm{HO}^{*}-\mathrm{Ru}-\mathrm{O} *-\mathrm{Ru}-* \mathrm{OH}\right\} \rightarrow \mathrm{H}_{2} \mathrm{O} *+\{-\mathrm{O} *-\mathrm{Ru}-\mathrm{O} *-\mathrm{Ru}-\square\}
$$

$$
\begin{aligned}
\mathrm{O}_{2}+\left\{-\mathrm{O}^{*}-\mathrm{Ru}-\mathrm{O}^{*}-\mathrm{Ru}-\right. & \\
& \left.\rightarrow-\mathrm{O}^{*}-\mathrm{Ru}-\mathrm{O} *-\mathrm{Ru}-\left(\mathrm{O}_{2}\right)\right\} \rightarrow \cdots \cdots
\end{aligned}
$$

In this sequence, the $\left\{-\mathrm{O}^{*}-\mathrm{Ru}-\mathrm{O}^{*}-\mathrm{Ru}-\mathrm{O}^{*}-\right\}$ is meant to depict in general $\mathrm{RuO}_{x}$ structures with reactive lattice oxygen atoms $\left(\mathrm{O}^{*}\right)$. These postulated elementary steps include dissociative $\mathrm{CH}_{3} \mathrm{OH}$ chemisorption to form methoxide $\left(\mathrm{CH}_{3} \mathrm{O}^{-}\right)$intermediates (Step 1), followed by hydrogen abstraction from $\mathrm{CH}_{3} \mathrm{O}^{-}$ using lattice oxygen atoms $\left(\mathrm{O}^{*}\right)$ in $\mathrm{RuO}_{x}$ to form HCHO (Step 2). $\mathrm{H}_{2} \mathrm{O}$ desorption via recombination of $\mathrm{OH}$ groups forms an oxygen vacancy ( $\square$ ) (Step 3), and $\mathrm{O}_{2}$ dissociative chemisorption (Step 4) ultimately restores the missing lattice oxygen in a series of steps that complete a Mars-van Krevelen redox cycle. ${ }^{1,19}$ These steps are consistent with the kinetic dependence of reaction rates on $\mathrm{CH}_{3} \mathrm{OH}$ and $\mathrm{O}_{2}$ partial pressures, as we discuss next.

Figure 3 shows $\mathrm{CH}_{3} \mathrm{OH}$ oxidative dehydrogenation rates and product selectivities as a function of $\mathrm{CH}_{3} \mathrm{OH}$ partial pressure $(0-40 \mathrm{kPa})$ at $393 \mathrm{~K}$ and $9 \mathrm{kPa} \mathrm{O}{ }_{2}$ on $\mathrm{RuO}_{2} / \mathrm{TiO}_{2}(3.1 \mathrm{Ru} /$ $\left.\mathrm{nm}^{2}\right)$. At similar conversions $(\sim 10 \%)$, ODH rates first increased almost linearly with increasing $\mathrm{CH}_{3} \mathrm{OH}$ pressure (below $8 \mathrm{kPa}$ ) and then more gradually, ultimately reaching nearly constant values above $12 \mathrm{kPa}$. This behavior indicates that active surfaces become saturated with $\mathrm{CH}_{3} \mathrm{OH}$-derived reactive intermediates (e.g., $\mathrm{CH}_{3} \mathrm{O}^{-}$) as $\mathrm{CH}_{3} \mathrm{OH}$ pressure increases. In parallel, $\mathrm{MF}$ and DMM selectivities increased (from 56.9 and 1.5\%, respectively) and approached constant values (80.2 and 9.1\%) with increasing $\mathrm{CH}_{3} \mathrm{OH}$ partial pressures; $\mathrm{HCHO}$ selectivities concurrently decreased from 42.5 to $10.3 \% . \mathrm{CO}_{x}$ selectivities were very 
TABLE 2: Methanol Oxidation Rates and Selectivities on Physical Mixtures of $\mathrm{RuO}_{2} / \mathrm{TiO}_{2}+\mathrm{Al}_{2} \mathrm{O}_{3}$, and $\mathrm{RuO}_{2} / \mathrm{Al}_{2} \mathrm{O}_{3}+\mathrm{TiO}_{2}$ at a Mass Ratio of 1/3, and for Comparison on $\mathrm{RuO}_{2} / \mathrm{TiO}_{2}\left(6.2 \mathrm{Ru} / \mathrm{nm}^{2}\right)$ and $\mathrm{RuO}_{2} / \mathrm{Al}_{2} \mathrm{O}_{3}\left(1.3 \mathrm{Ru} / \mathrm{nm}^{2}\right)^{a}$

\begin{tabular}{|c|c|c|c|c|c|c|}
\hline \multirow[b]{2}{*}{ catalyst (mass ratio) } & \multirow{2}{*}{$\begin{array}{c}\mathrm{CH}_{3} \mathrm{OH} \\
\text { conversion rate } \\
\text { (mol/g-atom Ru-h) }\end{array}$} & \multirow{2}{*}{$\begin{array}{c}\text { calculated } \\
\text { ODH rate } \\
\text { (mol/g-atom Ru-h) }\end{array}$} & \multicolumn{4}{|c|}{ selectivity (\% carbon) } \\
\hline & & & $\overline{\mathrm{HCHO}}$ & MF & DMM & $\mathrm{CO}_{x}$ \\
\hline $\mathrm{RuO}_{2} / \mathrm{TiO}_{2}+\mathrm{Al}_{2} \mathrm{O}_{3}(1 / 3)$ & 12.6 & 6.1 & 11.6 & 45.2 & 41.9 & 1.4 \\
\hline $\mathrm{RuO}_{2} / \mathrm{Al}_{2} \mathrm{O}_{3}+\mathrm{TiO}_{2}(1 / 3)$ & 13.8 & 6.5 & 6.2 & 60.4 & 32.6 & 0.8 \\
\hline $\mathrm{RuO}_{2} / \mathrm{TiO}_{2}$ & 10.9 & 6.6 & 24.9 & 65.2 & 8.9 & 1.0 \\
\hline $\mathrm{RuO}_{2} / \mathrm{Al}_{2} \mathrm{O}_{3}$ & 14.9 & 6.8 & 11.6 & 30.1 & 57.4 & 1.0 \\
\hline
\end{tabular}

${ }^{a} 393 \mathrm{~K}, 4 \% \mathrm{CH}_{3} \mathrm{OH}, 9 \% \mathrm{O}_{2}, 1 \% \mathrm{~N}_{2}, \sim 20 \% \mathrm{CH}_{3} \mathrm{OH}$ conversion. ${ }^{b}$ Rate for primary $\mathrm{CH}_{3} \mathrm{OH}$ oxidative dehydrogenation to $\mathrm{HCHO}$.



Figure 3. Effect of methanol partial pressure on rates of oxidative dehydrogenation (per g-atom $\mathrm{Ru}$ ) of $\mathrm{CH}_{3} \mathrm{OH}$ to $\mathrm{HCHO}$ and selectivities at $393 \mathrm{~K}$ on $\mathrm{RuO}_{2} / \mathrm{TiO}_{2}\left(3.1 \mathrm{Ru} / \mathrm{nm}^{2}, 9 \mathrm{kPa} \mathrm{O}, 1 \mathrm{kPa} \mathrm{N}\right.$, balance $\mathrm{He}$, $\mathrm{CH}_{3} \mathrm{OH}$ conversion: $\sim 10 \%$ ).

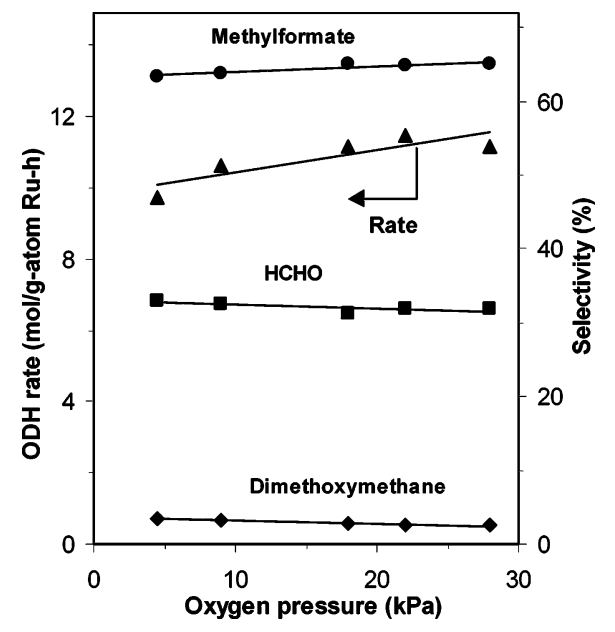

Figure 4. Effect of oxygen partial pressure on rates of oxidative dehydrogenation (per g-atom $\mathrm{Ru}$ ) of $\mathrm{CH}_{3} \mathrm{OH}$ to $\mathrm{HCHO}$ and selectivities at $393 \mathrm{~K}$ on $\mathrm{RuO}_{2} / \mathrm{TiO}_{2}\left(3.1 \mathrm{Ru} / \mathrm{nm}^{2}, 4 \mathrm{kPa} \mathrm{CH} \mathrm{CH}_{3} \mathrm{OH}\right.$, balance He, $\mathrm{CH}_{3} \mathrm{OH}$ conversion: $\sim 10 \%$ ).

low $(<1 \%)$, and they are not shown in Figure 3. These selectivity trends reflect the secondary nature of reaction pathways leading to MF and DMM synthesis, which require sequential bimolecular coupling between $\mathrm{HCHO}$ and $\mathrm{CH}_{3} \mathrm{OH}-$ derived intermediates (Scheme 1), the rate of which depends on pressure more sensitively than initial $\mathrm{HCHO}$ synthesis rates.

Figure 4 shows the effects of $\mathrm{O}_{2}$ partial pressure on oxidative $\mathrm{CH}_{3} \mathrm{OH}$ dehydrogenation rates and product selectivities on $\mathrm{RuO}_{2} / \mathrm{TiO}_{2}\left(3.1 \mathrm{Ru} / \mathrm{nm}^{2}\right)\left(393 \mathrm{~K}, 4 \mathrm{kPa} \mathrm{CH} \mathrm{CH}_{3} \mathrm{OH}\right)$. Reaction rates and selectivities were essentially unaffected by $\mathrm{O}_{2}$ partial pressures $(4.5-28 \mathrm{kPa})$. Such kinetic insensitivity to $\mathrm{O}_{2}$ concentrations is typical of catalytic oxidation reactions pro-
TABLE 3: Kinetic Isotopic Effects for Methanol Oxidation on $\mathrm{RuO}_{2} / \mathrm{TiO}_{2}$ at $393 \mathrm{~K}^{a}$

\begin{tabular}{lccc}
\hline & $\begin{array}{c}\mathrm{CH}_{3} \mathrm{OH} \\
\text { conversion rate } \\
\text { (mol/g-atom } \\
\text { Ru-h) }\end{array}$ & $\begin{array}{c}\text { calculated } \\
\text { ODH rate } \\
(\mathrm{mol} / \mathrm{g} \text {-atom } \\
\text { Ru-h) }\end{array}$ & $\begin{array}{c}\mathrm{MF} \\
\text { synthesis rate } \\
\text { (mol/g-atom } \\
\text { Ru-h) }\end{array}$ \\
\hline $\mathrm{CH}_{3} \mathrm{OH}$ & 16.3 & 10.5 & 11.4 \\
$\mathrm{CH}_{3} \mathrm{OD}$ & 15.8 & 10.3 & 10.9 \\
$\mathrm{CD}_{3} \mathrm{OD}$ & 6.5 & 4.4 & 3.7 \\
$k_{\mathrm{CH}_{3} \mathrm{OH}} / k_{\mathrm{CH}_{3} \mathrm{OD}}$ & 1.03 & $1.02(1.11)^{c}$ & 1.05 \\
$k_{\mathrm{CH}_{3} \mathrm{OH}} / k_{\mathrm{CD}_{3} \mathrm{OD}}$ & 2.51 & $2.38(3.33)^{c}$ & 3.07
\end{tabular}

a $3.1 \mathrm{Ru} / \mathrm{nm}^{2}, 4 \%$ methanol, $9 \% \mathrm{O}_{2}, \sim 10 \%$ methanol conversion. ${ }^{b}$ Rate for primary methanol oxidative dehydrogenation to formaldehyde. ${ }^{c}$ Data in parentheses were obtained on $\mathrm{Fe}_{2}\left(\mathrm{MoO}_{4}\right)_{3}$ at $473 \mathrm{~K}$ from ref 20.

ceeding via Mars-van Krevelen mechanism ${ }^{19}$ using lattice oxygen atoms on nearly stoichiometric surfaces, a finding confirmed by anaerobic transient $\mathrm{CH}_{3} \mathrm{OH}$ reaction data reported below. Measurements at $20 \mathrm{kPa} \mathrm{CH}_{3} \mathrm{OH}$ and varying $\mathrm{O}_{2}$ concentrations led to essentially identical trends and conclusions.

Methanol molecules deuterated at all positions $\left(\mathrm{CD}_{3} \mathrm{OD}\right)$ or only at the hydroxyl group $\left(\mathrm{CH}_{3} \mathrm{OD}\right)$ were used to probe the kinetic relevance of elementary steps involving methoxide formation and $\mathrm{H}$-abstraction from methoxide during $\mathrm{CH}_{3} \mathrm{OH}$ oxidation on $\mathrm{RuO}_{x}$ domains. Kinetically relevant methanol dissociation steps would lead to normal kinetic isotope effects (KIE) for both $\mathrm{CH}_{3} \mathrm{OD}$ and $\mathrm{CD}_{3} \mathrm{OD}$ reactants. In contrast, the kinetic relevance of $\mathrm{H}$-abstraction from $\mathrm{CH}_{3} \mathrm{O}^{-}$to form $\mathrm{HCHO}$ would lead to normal $\mathrm{KIE}$ for $\mathrm{CD}_{3} \mathrm{OD}$ and weak thermodynamic isotope effects for $\mathrm{CH}_{3} \mathrm{OD}$.

Table 3 shows kinetic isotope effects (defined as the ratio of $\mathrm{ODH}$ rates for undeuterated and deuterated methanol) measured at $4 \mathrm{kPa}$ methanol and $9 \mathrm{kPa} \mathrm{O}$ on $\mathrm{RuO}_{2} / \mathrm{TiO}_{2}$ at $393 \mathrm{~K}$. At these conditions, oxidation rates are linear in methanol concentration and independent of $\mathrm{O}_{2}$ pressure (Figures 3 and 4). $\mathrm{CD}_{3} \mathrm{OD}$ reactants gave kinetic isotope effects greater than 2 for the rate of each reaction (methanol total conversion, oxidative dehydrogenation, and methylformate synthesis). In contrast, each of these rates was almost unchanged when $\mathrm{CH}_{3} \mathrm{OD}$ was used instead of $\mathrm{CH}_{3} \mathrm{OH}$ as reactants (KIE values of 1.02-1.05). Thus, deuterium substitution at the methanol hydroxyl group is kinetically inconsequential, indicating that dissociative chemisorption to form methoxide species is quasi-equilibrated during oxidative $\mathrm{CH}_{3} \mathrm{OH}$ dehydrogenation on $\mathrm{RuO}_{x}$ domains.

These $\mathrm{CD}_{3} \mathrm{OD}$ and $\mathrm{CH}_{3} \mathrm{OD}$ kinetic isotope effects resemble those measured for $\mathrm{HCHO}$ synthesis on $\mathrm{Fe}_{2}\left(\mathrm{MoO}_{4}\right)_{3}$ at $473 \mathrm{~K}$ (Table 3), ${ }^{20}$ which led to conclusions about the kinetic relevance of methoxide $\mathrm{C}-\mathrm{H}$ bond activation similar to those reached here for $\mathrm{RuO}_{x}$-based catalysts. $\mathrm{CD}_{3} \mathrm{OD} \mathrm{KIE}$ values on $\mathrm{RuO}_{x}$ domains are smaller than on $\mathrm{Fe}_{2}\left(\mathrm{MoO}_{4}\right)_{3}$, even though the lower temperatures used on $\mathrm{RuO}_{x}$ catalysts would typically lead to larger isotope effects for identical reaction coordinate and ratedetermining step. This appears to indicate that transition states retain more reactant character during $\mathrm{H}$-abstraction on $\mathrm{RuO}_{x}$ 
catalysts; $\mathrm{C}-\mathrm{D}$ and $\mathrm{C}-\mathrm{H}$ bonds are consequently less disrupted within the activated complex along the reaction coordinate on $\mathrm{RuO}_{x}$ than on $\mathrm{Fe}_{2}\left(\mathrm{MoO}_{4}\right)_{3}$ catalysts. This leads, in turn, to smaller differences in reactivity between molecules containing $\mathrm{C}-\mathrm{H}$ and $\mathrm{C}-\mathrm{D}$ bonds. This shift toward reactant-like activated complexes becomes stronger as elementary steps become more exothermic, a process that also leads to lower activation energies, through ubiquitous Bronsted-Polanyi-type relations between kinetic and thermodynamic parameters, and to higher reaction rates. Thus, the lower KIE values measured on $\mathrm{RuO}_{x}$ catalysts are consistent with the observed ability of these materials to catalyze the overall reaction sequence, and the kinetically relevant $\mathrm{H}$-abstraction step, more effectively (and at lower temperatures) than $\mathrm{Fe}_{2}\left(\mathrm{MoO}_{4}\right)_{3}$.

The involvement of lattice oxygen atoms in $\mathrm{CH}_{3} \mathrm{OH}$ oxidation was confirmed by transient $\mathrm{CH}_{3} \mathrm{OH}$ reactions without $\mathrm{O}_{2}$ coreactants on $\mathrm{RuO}_{2} / \mathrm{TiO}_{2}$ at $393 \mathrm{~K}$. These data were obtained by removing reactants and reactive intermediates using a pure $\mathrm{He}$ purge for $300 \mathrm{~s}$ after steady-state catalytic reactions of $\mathrm{CH}_{3} \mathrm{OH}-$ $\mathrm{O}_{2}$ mixtures were carried out for $1.5 \mathrm{~h}$, and then introducing a $\mathrm{CH}_{3} \mathrm{OH}$-containing stream without $\mathrm{O}_{2}$ co-reactants. Figure $5 \mathrm{a}, \mathrm{b}$ show that removal of $\mathrm{O}_{2}$ from the reactant mixture did not initially influence ODH (or MF synthesis) rates or selectivities, indicating that lattice oxygen atoms are sufficient to form all reaction products observed during steady-state oxidation catalysis. These anaerobic rates decreased with time as lattice oxygen was gradually depleted by $\mathrm{CH}_{3} \mathrm{OH}$ oxidation events. In the process, methanol conversion decreased, leading to changes in product selectivity consistent with those obtained when conversion was varied instead by changing residence time (Figure 5b). The reintroduction of $\mathrm{O}_{2}$ into the $\mathrm{CH}_{3} \mathrm{OH}$ stream led to the rapid and complete recovery of the initial catalytic $\mathrm{CH}_{3} \mathrm{OH}$ conversion rates and selectivities (Figure 5a).

The characteristic time for reoxidation during these transients was much shorter than for oxygen depletion, consistent with rapid and kinetically irrelevant reoxidation steps and with low steady-state concentrations of oxygen vacancies during catalysis, as suggested by the kinetic analysis and mechanistic proposals described. The initial decay in methanol conversion rates with time can be accurately described by a first-order dependence on the concentration of remaining lattice oxygen atoms. The time constant obtained from fitting the resulting exponential function in time led to a turnover rate estimate of $33 \mathrm{~h}^{-1}$, which resembles steady-state turnover rates measured before and after these anaerobic transients and based on the dispersion of $\mathrm{RuO}_{2}$ clusters after reduction in $\mathrm{H}_{2}\left(53 \mathrm{~h}^{-1}\right)$. This agreement, although qualitative, is nevertheless remarkable; it confirms the accuracy of dispersion measurements and suggests that all lattice oxygen atoms in $\mathrm{RuO}_{2}$ domains exhibit similar reactivity in $\mathrm{H}$ abstraction reactions.

This transient behavior is characteristic of catalytic oxidations proceeding via Mars-van Krevelen mechanisms using lattice oxygen atoms. About 1.2 oxygen atoms were removed per $\mathrm{Ru}$ from $\mathrm{RuO}_{2}$ domains dispersed on $\mathrm{TiO}_{2}$ before methanol oxidation catalysis was suppressed; similar oxygen removal stoichiometries $(\mathrm{O} / \mathrm{Ru}=1.1-1.3)$ were observed for $\mathrm{RuO}_{x}$ domains supported on $\mathrm{ZrO}_{2}$ and $\mathrm{Al}_{2} \mathrm{O}_{3}$. These values indicate that $\mathrm{RuO}_{2}$ species prevalent during steady-state catalysis become unreactive as lattice oxygen is removed and the system undergoes a twoelectron reduction of $\mathrm{Ru}^{4+}$ centers $\left(\mathrm{Ru}^{4+} \rightarrow \mathrm{Ru}^{2+}\right)$ during anaerobic $\mathrm{CH}_{3} \mathrm{OH}$ reactions; they also show that reduction to $\mathrm{Ru}^{0}$ does not occur during either aerobic or anaerobic oxidation of $\mathrm{CH}_{3} \mathrm{OH}$ at conditions required for these reactions and that $\mathrm{RuO}$ species are unreactive in methanol activation at these

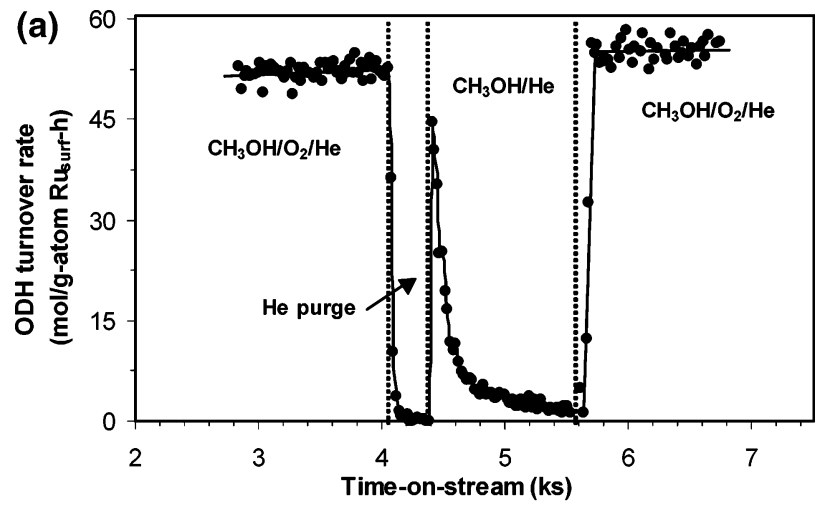

(b)

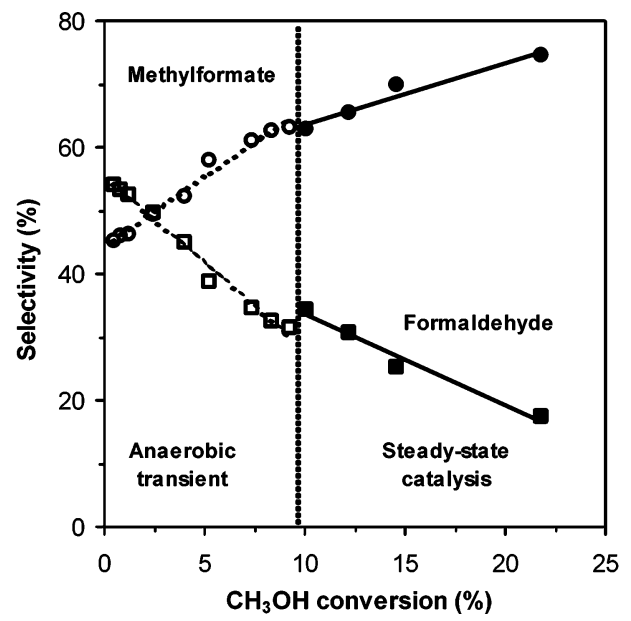

Figure 5. Oxidative dehydrogenation turnover rates (a) and $\mathrm{HCHO}$ and MF selectivities (b) during steady-state catalysis and during transient anaerobic oxidation of $\mathrm{CH}_{3} \mathrm{OH}$ on $\mathrm{RuO}_{2} / \mathrm{TiO}_{2}$. Conversion was varied by changing space velocity during steady-state catalysis and by allowing lattice oxygen depletion during anaerobic transients $\left(3.1 \mathrm{Ru} / \mathrm{nm}^{2}, 4 \mathrm{kPa}\right.$ $\mathrm{CH}_{3} \mathrm{OH}, 9 \mathrm{kPa} \mathrm{O}$ or no $\mathrm{O}_{2}$, balance $\mathrm{He}$ ).



Figure 6. $\mathrm{CH}_{3} \mathrm{OH}$ conversion turnover rates and selectivities as a function of $\mathrm{CH}_{3} \mathrm{OH}$ conversion changed by varying residence time (18610 g-atom Ru-s/mol CH $33 \mathrm{OH})$ at $393 \mathrm{~K}$ on $\mathrm{RuO}_{2} / \mathrm{TiO}_{2}\left(6.2 \mathrm{Ru} / \mathrm{nm}^{2}\right.$, fractional $\mathrm{Ru}$ dispersion: $0.125,4 \mathrm{kPa} \mathrm{CH}_{3} \mathrm{OH}, 9 \mathrm{kPa} \mathrm{O}, 1 \mathrm{kPa} \mathrm{N}$, balance $\mathrm{He})$.

reaction conditions. These conclusions are consistent with the weak kinetic consequences of $\mathrm{O}_{2}$ concentration on catalytic $\mathrm{CH}_{3} \mathrm{OH}$ oxidation rates (Figure 4).

Figure 6 shows the effects of $\mathrm{CH}_{3} \mathrm{OH}$ conversion, changed by varying residence time, on $\mathrm{CH}_{3} \mathrm{OH}$ conversion turnover rates and product selectivities at $393 \mathrm{~K}$ on $\mathrm{RuO}_{2} / \mathrm{TiO}_{2}\left(6.2 \mathrm{Ru} / \mathrm{nm}^{2}\right)$. 


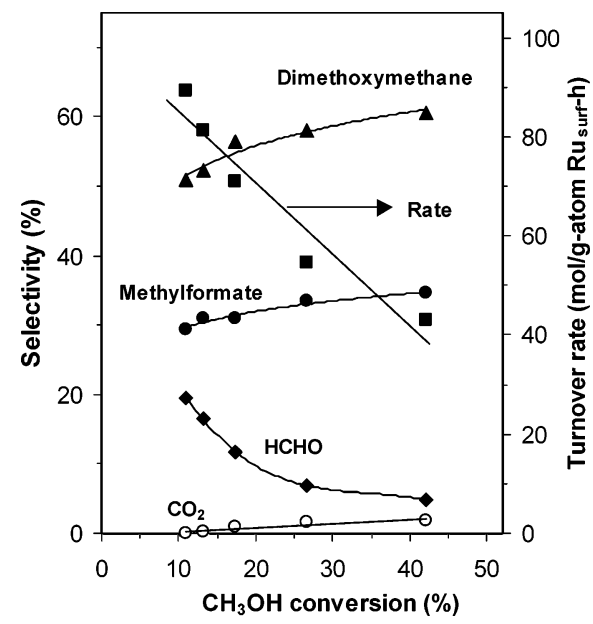

Figure 7. $\mathrm{CH}_{3} \mathrm{OH}$ conversion turnover rates and selectivities as a function of $\mathrm{CH}_{3} \mathrm{OH}$ conversion changed by varying residence time (35290 g-atom Ru-s/mol $\left.\mathrm{CH}_{3} \mathrm{OH}\right)$ at $393 \mathrm{~K}$ on $\mathrm{RuO}_{2} / \mathrm{Al}_{2} \mathrm{O}_{3}\left(1.3 \mathrm{Ru} / \mathrm{nm}^{2}\right.$, fractional $\mathrm{Ru}$ dispersion: $0.209,4 \mathrm{kPa} \mathrm{CH}_{3} \mathrm{OH}, 9 \mathrm{kPa} \mathrm{O}, 1 \mathrm{kPa} \mathrm{N}$, balance $\mathrm{He}$ ).

Turnover rates decreased with increasing residence time (and $\mathrm{CH}_{3} \mathrm{OH}$ conversion) as a result of reactant depletion, combined with weak kinetic inhibition effects by water co-products formed in oxidative dehydrogenation and condensation reactions. MF and DMM selectivities increased with increasing $\mathrm{CH}_{3} \mathrm{OH}$ conversion, while $\mathrm{HCHO}$ selectivity concurrently decreased, as expected from sequential pathways involving $\mathrm{HCHO}$ intermediates and the formation of MF and DMM. The nonzero MF selectivities observed as conversion decreases indicate that $\mathrm{MF}$ can be formed to some extent directly from $\mathrm{CH}_{3} \mathrm{OH}$, but also via readsorption of desorbed $\mathrm{HCHO}$ initial products, which tends to be favored as the concentration of $\mathrm{HCHO}$ increases with increasing residence time. $\mathrm{CO}_{2}$ selectivities were low $(0-8 \%)$ and increased with increasing residence time, suggesting that $\mathrm{CO}_{2}$ forms predominately via sequential oxidation or decomposition of $\mathrm{HCHO}, \mathrm{MF}$, and DMM products, and not via direct combustion of $\mathrm{CH}_{3} \mathrm{OH}$ reactants. No $\mathrm{CO}$ was detected at any reaction conditions, as expected from the high $\mathrm{CO}$ oxidation rates reported on $\mathrm{RuO}_{x}$ surfaces. ${ }^{11}$ Similar residence time effects on $\mathrm{CH}_{3} \mathrm{OH}$ conversion turnover rates and selectivities were observed on $\mathrm{RuO}_{2} / \mathrm{Al}_{2} \mathrm{O}_{3}\left(1.3 \mathrm{Ru} / \mathrm{nm}^{2}\right)$, on which DMM instead of $\mathrm{MF}$ is preferentially formed (Figure 7). This indicates that $\mathrm{CH}_{3} \mathrm{OH}$ oxidative conversion proceeds via similar reaction pathways (Scheme 1) on $\mathrm{RuO}_{x}$ domains dispersed on both supports.

These residence time and support effects suggest that $\mathrm{CH}_{3} \mathrm{OH}$ initially forms $\mathrm{HCHO}$, which then reacts to form DMM and MF via methoxymethanol $\left(\mathrm{CH}_{3} \mathrm{OCH}_{2} \mathrm{OH}\right)$ intermediates or hemiacetal adsorbed species. ${ }^{7} \mathrm{HCHO}$ acetalization with nucleophilic methoxides $\left(\mathrm{CH}_{3} \mathrm{O}\right)$ can lead to $\mathrm{CH}_{3} \mathrm{OCH}_{2} \mathrm{OH}$ intermediates, ${ }^{5,21-23}$ which condense with $\mathrm{CH}_{3} \mathrm{OH}$ on acid sites to form DMM in equilibrium-constrained reactions, or dehydrogenate on redox sites to form $\mathrm{MF}$ (and $\mathrm{H}_{2} \mathrm{O}$ ) in thermodynamically favored reactions catalyzed by either $\mathrm{RuO}_{x}$ domains or active supports. These reactions occur, at least in part, on support surfaces containing acid or dehydrogenation sites, leading to the observed effects of supports on selectivity. Molecular simulations have suggested that $\mathrm{CH}_{3} \mathrm{OCH}_{2} \mathrm{OH}$ dehydrogenation forms MF much faster than $\mathrm{HCHO}$ dimerization (Tischenko reaction) or $\mathrm{CH}_{3} \mathrm{OH}$ reactions with adsorbed formate $\left(\mathrm{HCOO}^{-}\right)$ on $\mathrm{V}_{2} \mathrm{O}_{5} .{ }^{22} \mathrm{CH}_{3} \mathrm{OCH}_{2} \mathrm{OH}$ was not detected during our study of $\mathrm{CH}_{3} \mathrm{OH}$ reactions on $\mathrm{RuO}_{x}$, apparently because of its unfavorable equilibrium and high reactivity.



Figure 8. $\mathrm{CH}_{3} \mathrm{OH}$ oxidation rates and selectivities as a function of fractional $\mathrm{Ru}$ dispersion at $393 \mathrm{~K}$ on $\mathrm{RuO}_{2} / \mathrm{TiO}_{2}$ at conversions of $\sim 15-$ $20 \%\left(0.8-13.1 \mathrm{Ru} / \mathrm{nm}^{2}, 4 \mathrm{kPa} \mathrm{CH} \mathrm{CH}_{3} \mathrm{OH}, 9 \mathrm{kPa} \mathrm{O}, 1 \mathrm{kPa} \mathrm{N}\right.$, balance $\mathrm{He})$.

$\mathrm{CH}_{3} \mathrm{OH}$ reaction rates (per Ru-atom) increased almost linearly with increasing $\mathrm{Ru}$ dispersion (changed by varying $\mathrm{Ru}$ content from 0.6 to $8.2 \mathrm{wt} \%$ ) on $\mathrm{TiO}_{2}$, indicating that turnover rates are essentially insensitive to $\mathrm{RuO}_{2}$ domain size in this dispersion range (Figure 8 ). The slightly lower turnover rate measured on the sample with the highest $\mathrm{Ru}$ dispersion reflects the lower reducibility expected for the prevalent small oxide domains, ${ }^{15}$ which was confirmed by $\mathrm{H}_{2}$ reduction rate measurements. Selectivities were influenced weakly by Ru content and dispersion. MF selectivities (at $15-20 \% \mathrm{CH}_{3} \mathrm{OH}$ conversion) increased slightly as dispersion increased (Figure 8), a trend that merely reflects a concomitant increase in exposed $\mathrm{TiO}_{2}$ surfaces, which catalyze secondary reactions of $\mathrm{HCHO}$ to form MF, relative to exposed $\mathrm{RuO}_{x}$ surfaces, which are required to form the required $\mathrm{HCHO}$ intermediates.

These $\mathrm{RuO}_{x}$ catalysts are compared with previously reported $\mathrm{CH}_{3} \mathrm{OH}$ oxidation catalysts in Table $1 . \mathrm{V}_{2} \mathrm{O}_{5}-\mathrm{TiO}_{2}$ prepared by coprecipitation and $\mathrm{MoO}_{3} / \mathrm{SiO}_{2}$ prepared via impregnation method catalyze MF synthesis with high selectivity ( $\sim 80$ and $95.9 \%$, at $\sim 75$ and $5 \%$ conversion, respectively); ${ }^{2,5}$ reaction rates are much lower than on $\mathrm{RuO}_{x}$ catalysts, even at the higher temperatures of these previous studies. $\mathrm{RuO}_{2} / \mathrm{TiO}_{2}(4.1 \mathrm{wt} \%$ ), gave reaction rates of $4.8 \mathrm{~mol} / \mathrm{g}$-atom $\mathrm{Ru}_{\text {total }}$-h at $78.2 \% \mathrm{CH}_{3} \mathrm{OH}$ conversion and $393 \mathrm{~K}$ (Figure 6), which exceed those reported on $\mathrm{V}_{2} \mathrm{O}_{5}-\mathrm{TiO}_{2}\left(\sim 3.4 \mathrm{~mol} / \mathrm{g}\right.$-atom $\mathrm{V}_{\text {total }}$-h at $\sim 80 \% \mathrm{CH}_{3} \mathrm{OH}$ conversion) at $433 \mathrm{~K}$, with comparable $\mathrm{MF}$ and $\mathrm{CO}_{2}$ selectivities of 70.4 and $7.9 \%$ (vs 80 and 5\%), respectively. High MF selectivities $(\sim 90 \%)$ have also been reported on Mo-Sn mixed oxides at $433 \mathrm{~K}$ at low reaction rates, ${ }^{3}$ but similar compositions led to much lower MF selectivities (47\% at $\sim 40 \% \mathrm{CH}_{3} \mathrm{OH}$ ) at $453 \mathrm{~K}$ in another study. ${ }^{4}$

$\mathrm{RuO}_{2} / \mathrm{SiO}_{2}\left(1.1 \mathrm{Ru} / \mathrm{nm}^{2}\right)$ and $\mathrm{RuO}_{2} / \mathrm{SnO}_{2}\left(2.5 \mathrm{Ru} / \mathrm{nm}^{2}\right)$ also convert ethanol- $\mathrm{O}_{2}$ reactant mixtures with high rates and selectivity to form acetaldehyde, diethoxyethane (acetal), and ethyl acetate at $393 \mathrm{~K}$ (Table 4). Neither diethyl ether nor $\mathrm{CO}_{x}$ products were detected. As in methanol reactions, ethanol oxidation turnover rates were higher when $\mathrm{RuO}_{2}$ domains were supported on $\mathrm{SnO}_{2}$ than on $\mathrm{SiO}_{2}$. Ethanol conversion rates increased with pressure and then reached a constant value; as $\mathrm{C}_{2} \mathrm{H}_{5} \mathrm{OH}$ pressure increased from 2 to $40 \mathrm{kPa}$, products shifted from acetaldehyde ( 97.3 to $17.6 \%$ ), formed in primary oxidative dehydrogenation steps, to diethoxyethane (0 to $81 \%$ ), which forms via condensation reactions favored kinetically and thermodynamically at higher $\mathrm{C}_{2} \mathrm{H}_{5} \mathrm{OH}$ pressures (Table 4). Residence time effects on selectivities showed that reaction 
TABLE 4: Ethanol Oxidation Rates and Selectivities on $\mathrm{RuO}_{2} / \mathrm{SiO}_{2}\left(1.1 \mathrm{Ru} / \mathrm{nm}^{2}\right)$ and $\mathrm{RuO}_{2} / \mathrm{SnO}_{2}\left(2.5 \mathrm{Ru} / \mathrm{nm}^{2}\right)$ at $393 \mathrm{~K}{ }^{a}$

\begin{tabular}{|c|c|c|c|c|c|c|c|}
\hline \multirow[b]{2}{*}{ catalyst } & \multirow{2}{*}{$\begin{array}{c}\mathrm{C}_{2} \mathrm{H}_{5} \mathrm{OH} \\
\text { pressure } \\
(\mathrm{kPa})\end{array}$} & \multirow{2}{*}{$\begin{array}{l}\text { ethanol conversion } \\
\text { turnover rate } \\
\left.\text { (mol/g-atom } \mathrm{Ru}_{\text {surf }}-\mathrm{h}\right)\end{array}$} & \multirow{2}{*}{$\begin{array}{c}\text { ODH } \\
\text { turnover rate }{ }^{b} \\
\left(\mathrm{~mol} / \mathrm{g} \text {-atom } \mathrm{Ru}_{\text {total }}-\mathrm{h}\right)\end{array}$} & \multicolumn{4}{|c|}{ selectivity (\%) } \\
\hline & & & & acetaldehyde & ethyl acetate & acetal & $\mathrm{CO}_{x}$ \\
\hline $\mathrm{RuO}_{2} / \mathrm{SiO}_{2}$ & 4 & 30.6 & 30.1 & 97.1 & 0 & 2.9 & 0 \\
\hline $\mathrm{RuO}_{2} / \mathrm{SnO}_{2}$ & 2 & 51.6 & 50.9 & 97.3 & 2.7 & 0 & 0 \\
\hline $\mathrm{RuO}_{2} / \mathrm{SnO}_{2}$ & 4 & 76.3 & 73.2 & 93.4 & 2.0 & 4.6 & 0 \\
\hline $\mathrm{RuO}_{2} / \mathrm{SnO}_{2}$ & 10 & 108.6 & 83.5 & 64.8 & 2.2 & 33.0 & 0 \\
\hline $\mathrm{RuO}_{2} / \mathrm{SnO}_{2}$ & 20 & 157.4 & 86.1 & 30.8 & 1.2 & 68.0 & 0 \\
\hline $\mathrm{RuO}_{2} / \mathrm{SnO}_{2}$ & 40 & 188.9 & 85.9 & 17.6 & 1.4 & 81.0 & 0 \\
\hline
\end{tabular}

${ }^{a} 9 \mathrm{kPa} \mathrm{O}_{2}, 1 \mathrm{kPa} \mathrm{N}, \sim 10-15 \% \mathrm{C}_{2} \mathrm{H}_{5} \mathrm{OH}$ conversion. ${ }^{b}$ Rate for primary oxidative dehydrogenation of $\mathrm{C}_{2} \mathrm{H}_{5} \mathrm{OH}$ to acetaldehyde.

pathways involve initial acetaldehyde formation in oxidative dehydrogenation steps and subsequent acetalization reactions of acetaldehyde and ethanol to form diethoxyethane.

To our knowledge, these supported $\mathrm{RuO}_{x}$ materials have not been previously used for the activation and conversion of $\mathrm{CH}_{3} \mathrm{OH}, \mathrm{C}_{2} \mathrm{H}_{5} \mathrm{OH}$, or other short-chain alcohols, even though $\mathrm{Ru}$ oxides catalyze the oxidation of more reactive $\mathrm{C}_{5}+$ alcohols in the liquid phase to form aldehydes and ketones at $\sim 373$ K. ${ }^{12-14}$ Idriss and co-workers ${ }^{24}$ adsorbed methanol on $\mathrm{RuO}_{2}$ and only $\sim 0.6 \%$ of the adsorbed methanol formed methylformate in stoichiometric reactions of methanol preadsorbed at ambient temperature. In this study, the reduction of $\mathrm{RuO}_{2}$ to $\mathrm{Ru}$ metal at $573 \mathrm{~K}$ in $\mathrm{H}_{2}$ led to higher stoichiometric MF yields ( $\left.\sim 11 \%\right)$, via non-oxidative reactions unrelated to those prevalent on $\mathrm{RuO}_{2} \cdot{ }^{24}$ These previous studies did not detect or report evidence for the remarkable activity and selectivity shown here for $\mathrm{RuO}_{x^{-}}$ based materials in selective oxidation reactions of $\mathrm{CH}_{3} \mathrm{OH}$ and $\mathrm{C}_{2} \mathrm{H}_{5} \mathrm{OH}$.

In marked contrast, the supported $\mathrm{RuO}_{2}$ domains reported here gave unprecedented $\mathrm{CH}_{3} \mathrm{OH}$ conversion rates and allow $\mathrm{CH}_{3} \mathrm{OH}$ oxidation reactions to proceed at significant rates near ambient temperatures with $>99 \%$ combined selectivities to useful formaldehyde, methylformate, and dimethoxymethane products. The mechanistic details and the marked effects of support on rate and selectivity reported here suggest significant opportunities for the kinetic coupling of these low-temperature oxidative $\mathrm{CH}_{3} \mathrm{OH}$ activation pathways with other catalytic functions, such as condensation, methylation, and hydration reactions of $\mathrm{HCHO}, \mathrm{MF}$, and $\mathrm{DMM}$ to form more complex oxygenate molecules, including those containing new $\mathrm{C}-\mathrm{C}$ bonds. The unique behavior of these supported $\mathrm{RuO}_{2}$ clusters is not restricted to $\mathrm{CH}_{3} \mathrm{OH}$ activation reactions, and it appears to extend to higher alcohols, ${ }^{25}$ thus providing opportunities for also converting ethanol to diethoxyethane (acetal) and acetaldehyde with high rates and selectivities near ambient temperatures.

\section{Conclusions}

Supported $\mathrm{RuO}_{2}$ domains on $\mathrm{SnO}_{2}, \mathrm{ZrO}_{2}, \mathrm{TiO}_{2}, \mathrm{Al}_{2} \mathrm{O}_{3}$, and $\mathrm{SiO}_{2}$ provide low-temperature paths for $\mathrm{CH}_{3} \mathrm{OH}$ activation to form $\mathrm{HCHO}$ and for its subsequent conversion to $\mathrm{MF}$ and DMM. The unprecedented ability of these materials to catalyze oxidative $\mathrm{CH}_{3} \mathrm{OH}$ near ambient temperatures leads to favorable thermodynamics and to selective kinetic paths for the formation of the products. This unique reactivity reflects the ability of small $\mathrm{RuO}_{2}$ domains to undergo fast redox cycles without significant formation of unselective Ru metal clusters. Turnover rates and selectivities depend on the nature of the support, which influences $\mathrm{RuO}_{2}$ reducibility and thus the rate of kinetically relevant hydrogen abstraction from adsorbed methoxide intermediates. The kinetic effects of $\mathrm{CH}_{3} \mathrm{OH}$ and $\mathrm{O}_{2}$ reactant concentrations and the results of transient anaerobic measure- ments are consistent with Mars-van Krevelen redox mechanisms requiring lattice oxygen atoms. $\mathrm{CD}_{3} \mathrm{OD}$ reactants led to normal kinetic isotope effects, while $\mathrm{CH}_{3} \mathrm{OD}$ and $\mathrm{CH}_{3} \mathrm{OH}$ oxidation rates were nearly identical, consistent with quasi-equilibrated methoxide formation and rate-determining $\mathrm{H}$-abstraction from methoxide intermediates. DMM forms via acid-catalyzed secondary reactions of $\mathrm{CH}_{3} \mathrm{OH}$ with intermediates derived from $\mathrm{CH}_{3} \mathrm{OH}-\mathrm{HCHO}$ acetalization reactions on support acid sites, while MF appears to form via $\mathrm{H}$-abstraction from these intermediates on $\mathrm{RuO}_{2}$ or support redox active sites. Acid sites on $\mathrm{Al}_{2} \mathrm{O}_{3}$ and $\mathrm{SiO}_{2}$ favor dimethoxymethane formation, while redox and amphoteric sites on $\mathrm{SnO}_{2}, \mathrm{ZrO}_{2}$, and $\mathrm{TiO}_{2}$ preferentially form methylformate. The effects of residence time and of mixing pure supports with supported $\mathrm{RuO}_{2}$ catalysts are consistent with these conclusions. These materials also catalyze the selective oxidation of ethanol to acetaldehyde and diethoxyethane at $300-400 \mathrm{~K}$.

Acknowledgment. The authors dedicate this manuscript to Professor Michel Boudart on the occasion of his 80th birthday and acknowledge with thanks his pioneering contributions to the science and applications of catalysis, as well as his mentorship of several generations of students, colleagues, and friends. This work was supported by BP as part of the Methane Conversion Cooperative Research Program at the University of California at Berkeley. This work was also supported in part by the Director, Office of Basic Energy Sciences, Chemical Sciences Division of the U.S. Department of Energy under Contract DE-AC03-76SF00098. The authors acknowledge the assistance of Ms. Patricia Cheung with the anaerobic transient experiments, as well as helpful technical discussions with Dr. Theo Fleisch of BP during the early stages of this study.

\section{References and Notes}

(1) Tatibouet, J. M. Appl. Catal. A 1997, 148, 213.

(2) Tronconi, E.; Elmi, A. S.; Ferlazzo, N.; Forzatti, P.; Busca, G.; Tittarelli, P. Ind. Eng. Chem. Res. 1987, 26, 1269.

(3) Ai, M. J. Catal. 1982, 77, 279.

(4) Valente, N. G.; Arrua, L. A.; Cadus, L. E. Appl. Catal. A 2001, $205,201$.

(5) Louis, C.; Tatibout, J. M.; Che, M. J. Catal. 1988, 109, 354.

(6) Yuan, Y.; Iwasawa, Y. J. Phys. Chem. B 2002, 106, 4441

(7) Liu, H.; Iglesia, E. J. Phys. Chem. B 2003, 107, 10840.

(8) Busca, G. Catal. Today 1996, 27, 457.

(9) Liu, Y. C.; Griffin, G. L.; Chan, S. S.; Wachs, I. E. J. Catal. 1985, 94, 108.

(10) Kolah, A. K.; Mahajani, S. M.; Sharma, M. M. Ind. Eng. Chem. Res. 1996, 35, 3707.

(11) Zang, L.; Kisch, H. Angew. Chem., Int. Ed. 2000, 39, 3921.

(12) Zhan, B. Z.; White, M. A.; Sham, T. K.; Pincock, J. A.; Doucet, R. J.; Rao, K. V. R.; Robertson, K. N.; Cameron, T. S. J. Am. Chem. Soc. 2003, 125, 2195.

(13) Yamaguchi, K.; Mizuno, N. Angew. Chem., Int. Ed. 2002, 41, 4538.

(14) Musawir, M.; Davey, P. N.; Kelly, G.; Kozhevnikov, I. V. J. Chem. Soc. Chem. Commun. 2003, 1414.

(15) Liu, H.; Cheung, P.; Iglesia, E. J. Catal. 2003, 217, 222. 
(16) Chen, K.; Xie, S.; Bell, A. T.; Iglesia, E. J. Catal. 2001, 198, 232. (17) Mar, S. Y.; Chen, C. S.; Huang, Y. S.; Tiong, K. K. Appl. Surf. Sci. 1995, 90, 497.

(18) Desikan, A. N.; Zhang, W.; Oyama, S. T. J. Catal. 1995, 157, 740

(19) Mars, P.; van Krevelen, D. W. Chem. Eng. Sci. 1954, 3, 41.

(20) Machiels, C. J.; Sleight, A. W. J. Catal. 1982, 76, 238.

(21) Wachs, I. E.; Madix, R. J. Surf. Sci. 1978, 76, 531.
(22) Sabeth, J.; Juan, A.; Gambaro, L.; Thomas, H. J. Mol. Catal. A 1997, 118,283

(23) Tatibouet, J. M.; Lauron-Pernot, H. J. Mol. Catal. A 2001, 171, 205.

(24) Madhavaram, H.; Idriss, H.; Wendt, S.; Kim, Y. D.; Knapp, M.; Over, H.; Assmann, J.; Loffler, E.; Muhler, M. J. Catal. 2001, 202, 296. (25) Liu, H.; Iglesia, E. U.S. Patent Application, 2003. 